\title{
Project Management of the Formation and Implementation of State Programs for the Russian Defence Industrial Complex Development
}

\author{
Golubev S.S. \\ Moscow Polytechnic University, \\ Moscow, Russia, \\ consult46@bk.ru \\ Shcherbakov A.G. \\ ASPI Group, \\ Moscow, Russia, \\ m.a.izmailova@mail.ru
}

\author{
Shutova T.V. \\ LEONOV Moscow Region University of Technology, \\ Korolyov, Russia, \\ shutova@ut-mo.ru \\ Daneykin Yu.V. \\ Yaroslav-the-Wise Novgorod State University, \\ Veliky Novgorod, Russia, \\ Yury.Daneykin@novsu.ru
}

\begin{abstract}
An important factor in the successful defence industrial complex (DIC) enterprises development is their active innovation, which can only be provided by modern enterprise management tools. The purpose of the research is to develop guidelines for the project management implementation during the activities and projects contained in the state programs of the Russian Federation (hereinafter referred to as state programs) implemented at the DIC enterprises. The study was carried out using methods of analysis of historical sources on managing Russian and foreign enterprises projects, an integrated and systematic approach to DIC enterprises management. In the course of the research, the goals of implementing project management in DIC development were determined, the specifics of managing innovative projects were revealed, and the possibilities of using the project approach in the implementation of state programs for the Russian DIC development were revealed. The novelty of the results obtained lies in the development of a scientific and methodological apparatus for introducing project approach to managing the implementation of state programs of the Russian Federation in the field of the DIC development, which are important for the Armed Forces of the Russian Federation modern technical means and infrastructure creation. The widespread use of project management in the DIC development will save time and money spent on the implementation of state programs for the DIC development in Russia. The development of project management in the DIC will contribute to a more effective performace of defence enterprises, increase the controllability level of their innovative and investment development, which, as a result, will have a positive effect on the growth of the innovative projects implementation efficiency.
\end{abstract}

Keywords-project management, state development programs, innovations, investments, conceptual approaches, defence industrial complex enterprises

\section{INTRODUCTION}

The relevance of the research topic is due to the need to ensure effective activities for the development of the high-tech state defence complex, in order to meet the Armed Forces of the Russian Federation need for modern weapons, military and special equipment (WMSE) in the new economic conditions, as well as to ensure the competitive presence of the state in WMSE world markets. The main factor in achieving this goal is the defence industrial complex (DIC) enterprises innovative activity, which is carried out through the innovative projects implementation.

The project-based approach to solving practical problems with limited time and financial resources has shown its effectiveness all over the world, including the public sector management. Today, many Western leaders talk about the importance of projects for the economy of the state, for its development and positioning. Project management is becoming an integral and important element of the management culture in public authorities, including the management of the formation and implementation of state programs of the Russian Federation in the field of the Russian DIC.

The introduction of project management into the practice of managing state programs is quite a complex and systemic task, the solution to which is associated with a change in the currently existing management processes not only in the public sector, but also at the DIC enterprises. Project management today is one of the main tools for effective management in public authorities [1]. Therefore, today, it is very important for Russia to formulate guidelines for the project management mechanism implementation within the framework of existing state programs and, especially in the DIC development, which are implemented in order to ensure 
the fulfillment of the tasks of the State Armament Program (SAP), implemented through accomplishing the state defence order (SDO) by defence enterprises [2].

In this regard, the existing methodological and regulatory support of the implemented state programs is of serious concern about the need to introduce project management. In practice, this leads to a decrease in the effectiveness of government programs in the field of DIC development and project activities in general.

The hypothesis of the research is that the introduction of project management in the formation and implementation of state programs related to the DIC of the Russian Federation development will contribute to their more efficient implementation, increase the level of management efficiency in the innovative development of industrial enterprises and will contribute to an increase in the efficiency of innovation implementation in the DIC. However, the specificity of the DIC enterprises activities requires clarification of the conceptual principles, methods and means of introducing project management in the state programs formation and implementation and at the DIC enterprises that implement them.

\section{Methodology}

The project management concept is based on the "project" idea. At the same time, the project is considered not only as a management object, which has some inherent properties, but also as a general characteristic of its essence and as a basic feature of project management. The basis of the project management concept is a conceptual view of the project as a change in the system state, which will be due to the time and money expenditure. Project management will be the process of making these changes according to certain rules. To this can be added the provision of an acceptable degree of risk, the implementation of which is aimed at achieving the goal (creation of a new product or service). The project approach concept includes a set of principles presented in Fig. 1.

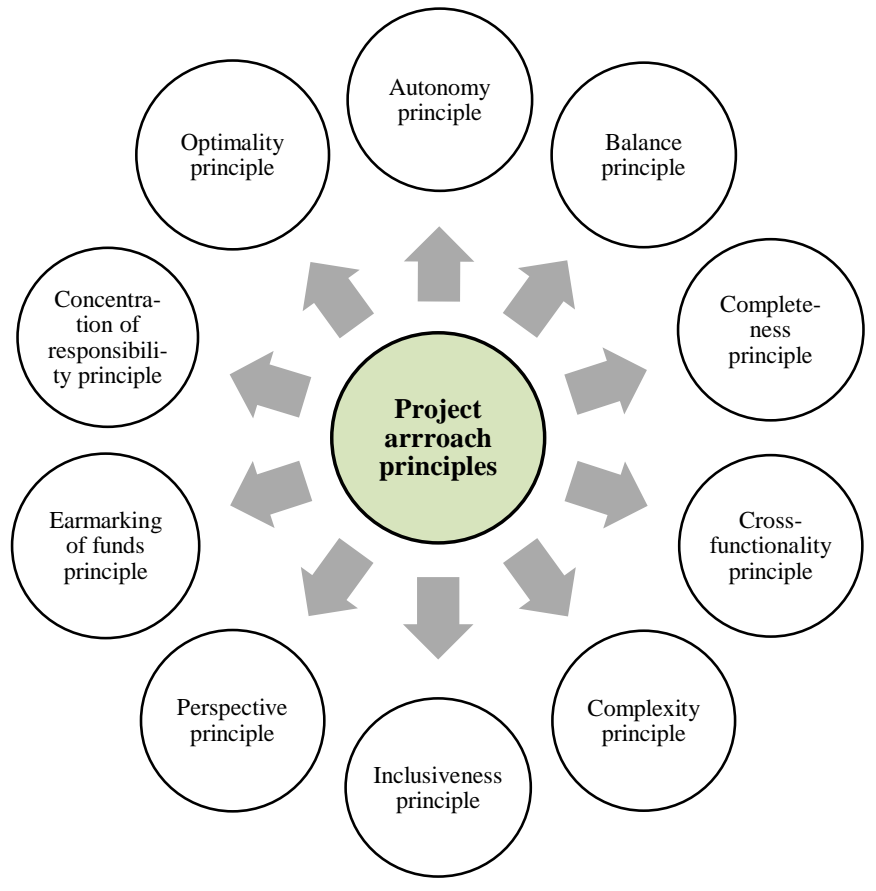

Fig. 1. Project approach principles [3]
In the project approach, these principles are used together, and when used separately, they are already related to other management processes.

It is advisable to apply project management if there are certain restrictions related to time, quality of performance, financial resources, complexity, acceptable degree of risk, complexity, labour intensity, task importance, etc. The result of applying the project approach should always exceed its organization relevant costs.

When developing guidelines for the project management implementation in the framework of state programs, the methods of system analysis, situational modeling, operations research and statistical decisions were used as tools, and general scientific (observation, analysis, synthesis), logical, complex and systematic approaches were used in evaluating management actions and decision-making.

In accordance with the methods of historical research, in order to develop general theoretical principles of project management in an industry with specific features, a comprehensive and systematic analysis of project management sources was carried out both in Russia and abroad.

\section{RESULTS}

\section{A. Analysis of the existing state programs of the Russian Federation in the field of DIC development and problems of their implementation}

Federal Law No 172-FZ of June 28, 2014 "On Strategic Planning in the Russian Federation" includes ensuring the achievement of the outlined strategic goals and solving the priority tasks of state policy through the formation and implementation of state programs. The list of such programs was approved by the order of the Government of the Russian Federation dated November 11, 2010 No 1950-r [4, 5].

The main tools for achieving the outlined strategic goals and solving priority tasks of state policy are state programs which are being implemented, including in the DIC development. The state program is understood as a system of measures, as well as instruments which will ensure the achievement of goals and priorities of state policy, as well as the security of the state and its sustainable socio-economic development.

In accordance with the List of state programs, 44 state programs have been formed, 40 of which are currently being implemented [6]. The list of the current state programs of the Russian Federation was approved by the order of the Government of the Russian Federation of November 11, 2010 No 1950-r. The state programs of the Ministry of Industry and Trade of the Russian Federation in the field of the DIC development are presented in Fig. 2 [7].

The Court of Auditors of the Russian Federation, when carrying out inspections of the implementation of state programs, mentioned a number of shortcomings in their formation and implementation [8]. The goals of a number of state programs are not specific, their ambiguous interpretation is allowed, at the same time, the tasks do not meet the requirements of their sufficiency, as well as the need to ensure the achievement of the goal. This does not allow to properly monitor the state programs implementation. The indicators of 
certain state programs of the Russian Federation are not consistent with the indicators of strategic planning.

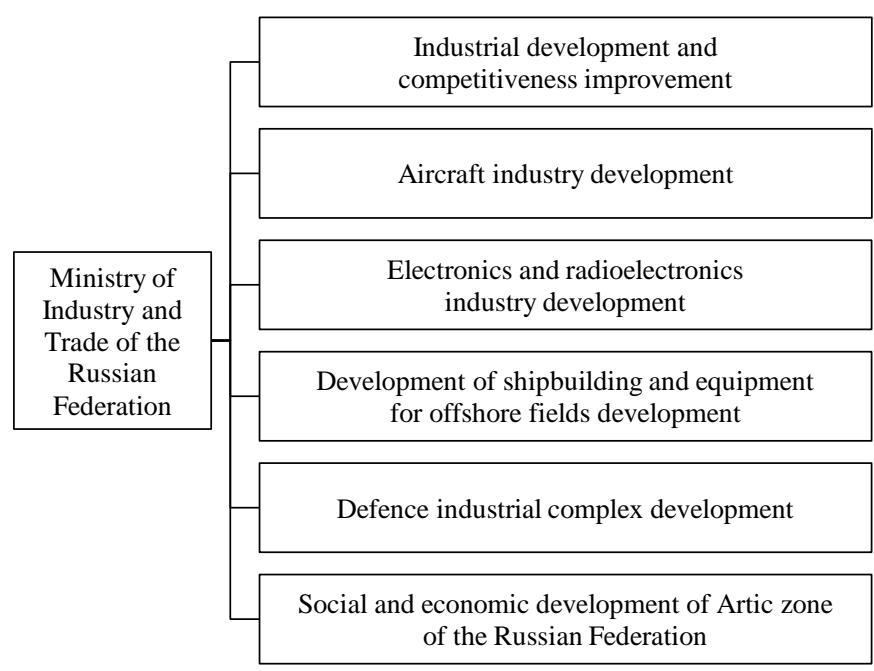

Fig. 2. State programs of the Ministry of Industry and Trade of Russia in the DIC development

A decrease in the number of overfulfilled target indicators has been noted for certain state programs. For example, in 2018, the number of overfulfilled indicators decreased from 254 indicators to 91 indicators, while the average degree of the indicators overfulfillment increased by more than 6 times (Fig. 3) [9], which indicates an underestimation of key program indicators.

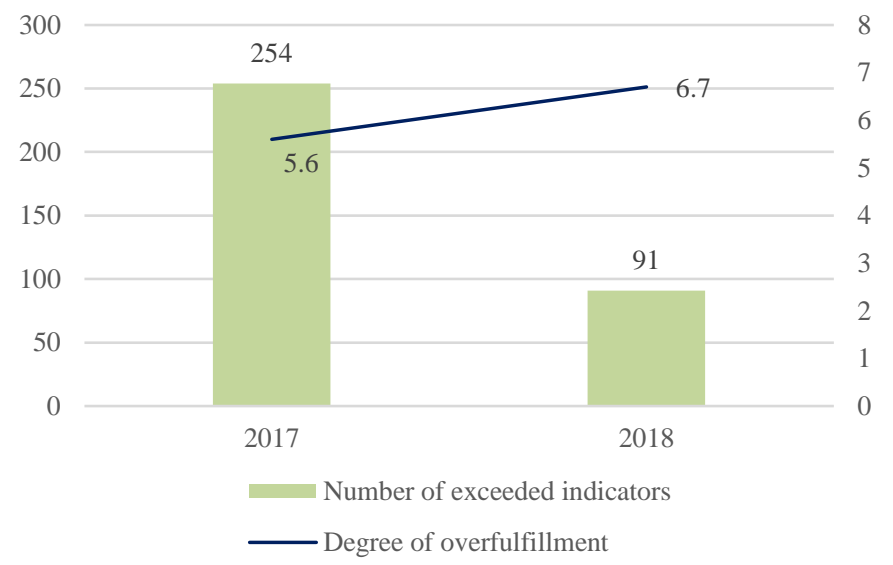

Fig. 3. The number of overfulfilled indicators of state programs and the degree of their overfulfillment

Individual government programs are linked to other government programs, and such links are not always analyzed. This leads to the formation of risks of failing to meet target indicators. Financial risks, caused by the enterprises not complying the terms of financing programs, are not managed. In some programs, such an important indicator as the growth of labour productivity is not set. The facts of target indicators underestimation are allowed to ensure their overfulfillment [9].

As a result, the parameters of government programs are often revised, there is an additional need for budget financing, both for the next financial year and for the next planning period. These facts do not contribute to the effectiveness of the budgetary funds usage and do not allow to realistically assess the achievement of the planned result.

\section{B. Conceptual approaches to the project management principles implementation in the defence industry}

The emergence of project management as an independent area of knowledge occurred as a result of the awaraness of the need to use new forms of management in solving complex technical problems in large-scale projects (primarily the DIC). In a broader sense, it can be mentioned that the characteristics of a developing society in the second half of the twentieth century (the exponential growth of accumulated knowledge, the increasing need for complex products and the development of global competitive markets) determined the new project management methods development and application.

The project management system was formed in the Ministry of Industry and Trade of Russia. The Ministry of Industry and Trade of Russia took first place among federal executive authorities in organizing project management. In the department of regional industrial policy and project management, a project office was created - the Center for Project Management in Industry. The necessary regulatory documents for the project activities organization were issued [10].

The concept of project management at DIC enterprises should be aimed at creating a methodology which includes analytical processing of planned work, organizational modeling, control and regulation of the new types of military equipment development and pilot production.

The operational activities of the enterprise are carried out in accordance with the enterprise strategy, which makes it possible to manage projects in accordance with the methodology of project management and at the same time obtain high results of the enterprise's activities. At the same time, project management acts as an effective mechanism that affects the controlled system and ensures the achievement of the goal within the given time frame and with limited resources [11].

In pilot production of DIC organizations, project management must comply with the basic principles shown in Fig. 4 [12].

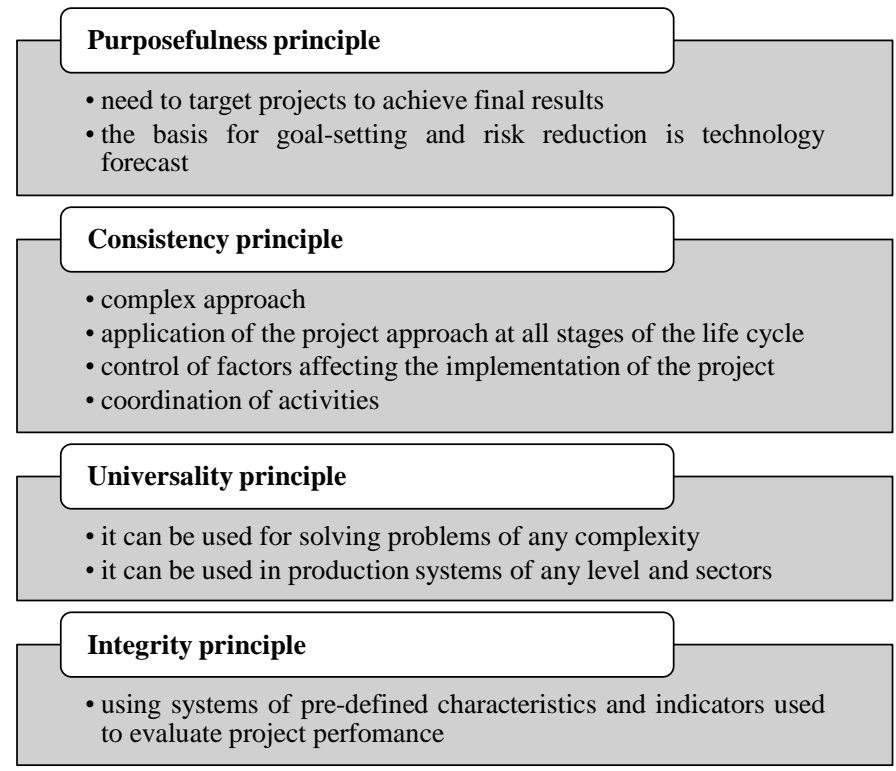

Fig. 4. Basic principles of implementing project management in enterprises 
The integrity principle in project management provides for using predetermined indicators system when developing projects. They are formed in the process of monitoring project activities and form the basis for assessing the effectiveness and efficiency of projects. At the same time, the use of different design methods at different stages of the life cycle of high-tech projects significantly increases the efficiency of project implementation.

The integrity principle provides for the inclusion of other production management systems in the project management system, and also ensures the optimization of the resource usage. At the same time, the accumulated experience, as well as the previously used design models, can be actively used in other projects [12] (Fig. 5).

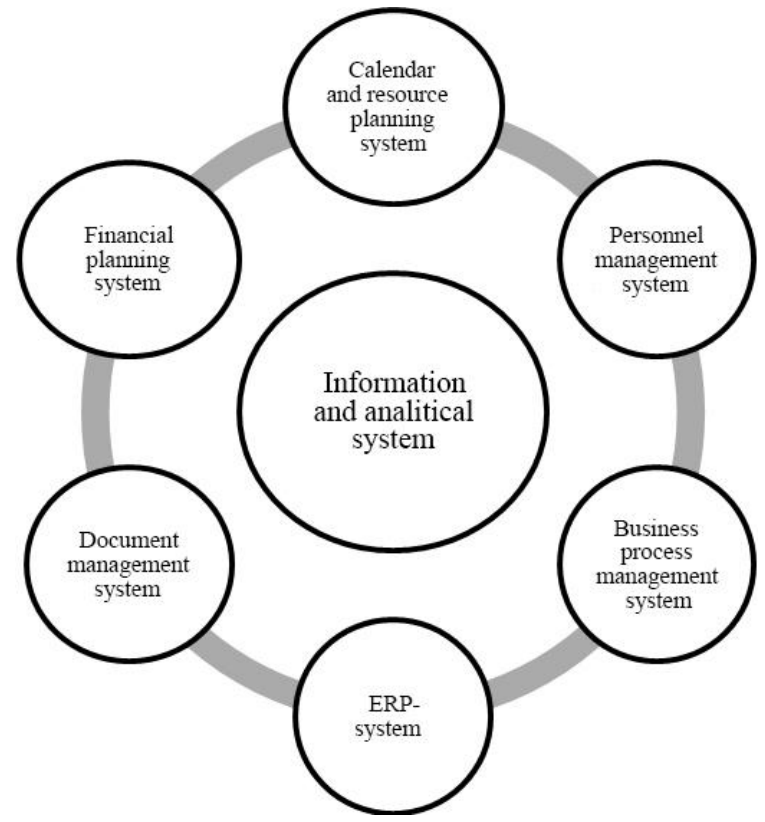

Fig. 5. Integration approach in project management system

The compliance of project management with the considered principles will ensure the management of sustainability, adaptability, as well as the possibility of improvement and development. This factor is the main characteristic of innovative management, and also contributes to the achievement of a synergistic effect in the process of implementing the goals of the project activities of enterprises for the production of defence-industrial products, which are distinguished by a high level of competitiveness in the world armament market.

Project management links the principles of project management and business practice together and becomes the basis for the implementation of the existing enterprise development strategy. The implementation of the project management concept is expected to involve all participants of managerial decisions making in projects implementation. In this case, the project management concept should be considered as a document of a higher level than project management. At the same time, project management must be in the focus of the project management concept in order to optimize the work of industrial enterprises on implementing the strategy [13].

When implementing project management for a specific project, it is necessary to use the whole set of project management methods. There is no project management methodology that is universal for all projects and industrial enterprises. The order of project management for each industrial enterprise is developed considering its accumulated experience, best practices and recommendations proposed by the standards of research organizations. The complex of the Project Management Institute (PMI) developments is an example of such recommendations is $[14,15]$.

\section{Guidelines for the formulation and control of the achievement of the goals of state programs}

An analysis of the implementation of state programs by the Court of Auditors of the Russian Federation showed that the system of goals and expected results is often not associated with strategic priorities of socio-economic development and does not allow to assess effectiveness of the executive authorities' activities in the state programs implementation.

The state program can have no more than 5 goals, which should reflect the strategic goals of the development of Russia, rely on indicators of socio-economic development of Russia and comply with the "SMART" principles [16].

Each element in this system has a meaning: for recognizing the goal, for its formation and achievement. Moreover, if a correct formulation of the planned tasks, according to the "SMART" system, is created, the transformation of projects often occurs - previously unnoticed important aspects, nuances, details emerge.

The goals of introducing project management for the implementation of state programs of the Russian Federation in the field of the DIC development should provide for an increase in the speed, quality and efficiency of the state programs implementation, guaranteed their achievement, an increase in competitive advantages, and also ensure the transparency and controllability of project activities.

The priority tasks of the production project management at DIC enterprises should be to accelerate development and produce new products, to implement high-quality government programs in the field of DIC development, to fulfill plans for diversification and import substitution of products and components, to continuously modernize production and technological base.

To solve problems in this area, DIC enterprises have to master modern management technologies, learn to speak the same language of project management with investors and other counterparties from different industries.

The problem of assessing the results of the state programs implementation is not new and requires special attention. On one hand, each state program has criteria for its assessment, expressed in specific indicators, and on the other hand, when considering the reporting on the state programs implementation, it should be mentioned that its content does not reflect the situation in dynamics, which does not allow to fully draw conclusions and predict certain changes properly and, accordingly, develop the required measures [17].

Evaluation of the government programs effectiveness is currently carried out according to a single methodology for assessing the effectiveness of the government programs implementation. The methodological approach to assessing the state programs implementation is set out in the methodology 
for assessing the effectiveness of the state programs of the Russian Federation implementation, approved by Decree of the Government of the Russian Federation of July 17, 2019 No 903 (as amended on April 16, 2020) "On Approval of the Rules for the Formation of a Consolidated Annual Report on the Implementation Progress and Performance Assessment State Programs of the Russian Federation" [18]. This methodology allows to calculate the marker characterizing the target indicators achievement degree, as well as the correspondence between the actual level of costs for the state program implementation and the planned one.

To monitor the achievement of goals and assess the effectiveness of government programs in the DIC sphere, it is currently required to develop indicators reflecting the degree to which the goals of the SAP implementation are achieved, and for a quantitative assessment, the indicator should show how the state program for the DIC development supports and ensures the SAP feasibility.

The structure of the state program and its organizational part should be linked to specific priority models of weapons, military and special equipment (WMSE) and DIC enterprises responsible for the development and production of these products. Such program structuring will make it possible to detail and consolidate responsibility for the implementation of program activities and SAP goals. With regard to the defence and security of the Russian Federation, the results of the state programs implementation should contribute to the formation of a scientific and technical reserve for the new highly competitive WMSE, as well as the widespread use of breakthrough industrial technologies.

\section{Digitalization of the project management process in the state programs implementation}

Undoubtedly, the greatest effect will be obtained from the implementation of the project approach in conjunction with the introduction of an automated information system in the field of project management. Almost all modern project management programs are able to integrate with other services and facilitate team communication. Automated project management makes it possible to structure risks - the most difficult process is to optimize. For example, systems can report ahead on risks in financial matters or in the context of delivering the right resources.

The project management information system (PMIS) is used by $91 \%$ of the surveyed representatives of the public sector. The most popular PMIS platforms (43\% of users) are solutions based on the Microsoft platform (Microsoft Project, Microsoft Project Server, Microsoft SharePoint). The main functionality used in them is scheduling, project workflow, control over the execution of orders and project reporting (Fig. 6)

Undoubtedly, domestic software products are needed to manage state programs in the DIC sphere. Linux-based programs and technologies for servers, workstations and thin clients with built-in information security software are considered to be promising. It can be used to build automated systems which allow storing and processing confidential data on one personal computer or server, providing multi-user work with delimiting access to information, working with virtual machines and using centralized authorization tools.

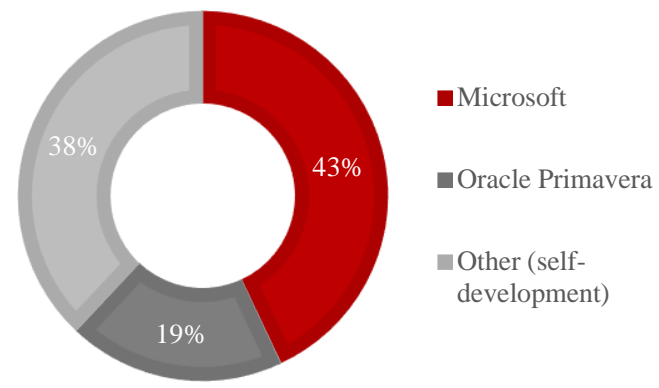

Fig. 6. The share of various platforms in the total volume on the basis of which the PMIS is built [19]

With the digitalization of the project management process, planning for the project provision with material resources is simplified. Project expenses can be considered in the context of the individual work cost, the cost of the performers' work and the time of their employment, the use of a specific resource or an hour of equipment operation.

\section{DISCUSSION}

A. The main reasons for introducing the project management principles into the system of state programs formation and implementation

Project management is an essential element of competitive advantage, and the organizations competence in project management and their ability to restructure quickly plays a key role in a country's competitiveness. In the next 20 years, the main thing for organizations will be the ability to adapt to the dynamics of the external environment, to the dynamics of today's world. It is not the strongest or the richest who will win, but the one who is able to make decisions faster, to quickly adapt to the current situation in the international and domestic arena.

The main reasons for introducing project management into the state programs of the Russian Federation management are shown in Fig. 7. Project management is a response to objective changes in the external environment (political, economic, social, etc.).

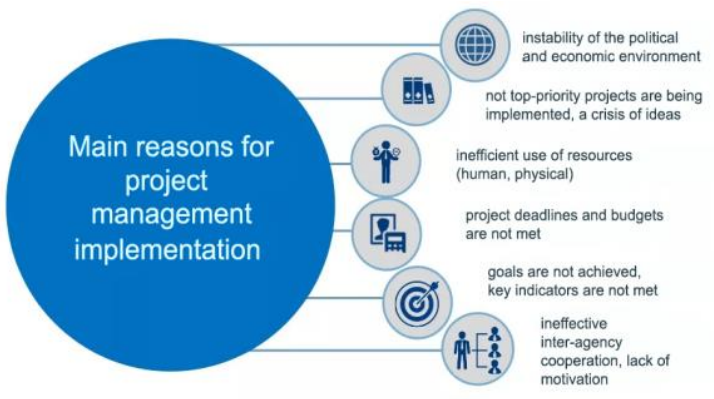

Fig. 7. The main reasons for the project management implamantation in the management of state programs of the Russian Federation

Resolutions of the Government of the Russian Federation of October 12, 2017 No 1242 approved the Rules for the Development, Implementation and Evaluation of the Effectiveness of Pilot State Programs, which are being transferred to project management mechanisms [20]. 
Pilot state programs were identified to be transferred to project management mechanisms (hereinafter referred to as pilot state programs). Transferring five state programs to the principles of project management means changing the rules for formulating their goals, the procedure for selecting projects and departmental target programs (DTP), the procedure for financing them, monitoring the achievement of goals and evaluating efficiency. The state programs of the Ministry of Industry and Trade of Russia in the sphere of the DIC development the main of which is the "Defence Industrial Complex Development" program, were also transferred to the principles of project management.

To implement the state program for the DIC development, during its creation, they focus on large enterprises - the lead developers of the WMSE final samples. The activities of the program are formed with their direct participation, with an increase in their role and responsibility for the implementation of the results of the DIC technological work in specific WMSE samples.

The most effective application of the project approach is at science-intensive and high-tech DIC enterprises, as well as in the oil and gas industry and construction. Project management has shown a good effect in the implementation of projects related to the introduction of digital technologies and projects of high socio-economic importance. The introduction of project management is aimed at increasing the efficiency of not only state programs implementation, but also public administration in general. The introduction of project management in the development and implementation of the state armament program, as well as other state programs in the field of the DIC development should increase the efficiency of their implementation.

\section{B. Complience of the research hypothesis to the results obtained}

The undertaken studies have shown that the results obtained comply to the hypothesis of the study and the application of project management principles at the DIC enterprises allows to obtain the following advantages, shown in Fig. 8.

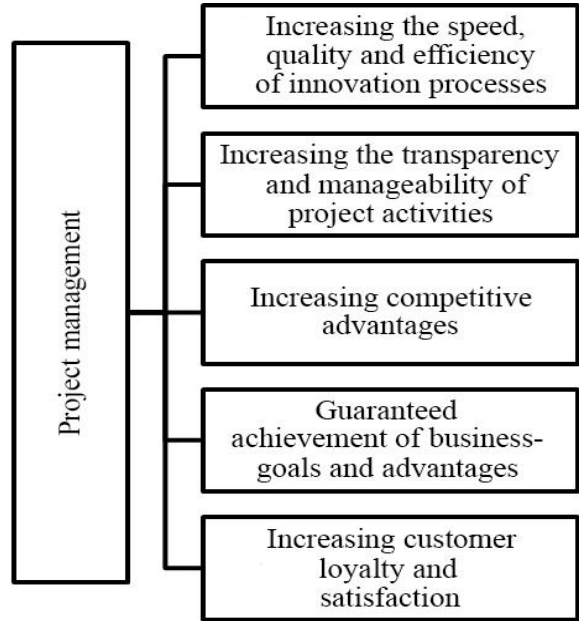

Fig. 8. Advantages of project management implamantation

As a result of the introduction of project management in the state programs for the DIC development implementation, the following positive results appear:
- acceleration of the development and production of promising highly competitive DIC products to increase the level of equipment of the Armed Forces of the Russian Federation with new WMSE models;

- it becomes possible to implement state and federal target programs in the field of the defence industrial complex development in full and in accordance with the budget;

- an effective cooperation system between enterprises and scientific organizations is being created with the aim to integrate technical as well as technological innovations in the production of highly competitive DIC products;

- the production of defence enterprises is being modernized, advanced equipment and technologies are being introduced, which would be aimed at improving the technical equipment and updating the weapons and military special equipment in service;

- plans on replacing imported products in terms of components, raw materials, materials when fulfilling the state defence order are being implemented;

- a technological audit is being introduced and the range of production of specialized high-tech civilian products is being expanded;

To solve problems in this area, the DIC enterprises must master modern management technologies, learn to speak the same language of project management with investors and other counterparties from different industries and different countries.

\section{Limitations of the study and the results obtained}

It is necessary to pay attention to the complexity of the project management system and departmental target programs which ensure the state programs of the Russian Federation implementation in the DIC development. The indicators they are composed of are embedded in state programs. This blurs the focus, complicates the management of these projects.

In this regard, it is necessary to change the management system for these projects. The project approach in this case is only a part of a wider range of public administration tools.

Projects and departmental target programs as part of pilot state programs must undergo a ranking procedure in accordance with the guidelines set out in the order of the Government of the Russian Federation dated November 11, 2010 No 1950-r [5].

The results of the ranking make it possible to determine the security of the program's objectives and achieve its specified target values, as well as to determine those projects (programs) which have the greatest value and the best feasibility within the limited state budgets for their subsequent selection and inclusion in the pilot state program.

\section{Changes to the corporate system in the project management implementation}

When implementing project management at the level of enterprise management, an understanding of the necessary model of the corporate project management system will be 
formed, which will allow to correctly build a system of strategic goals and operational tasks during the transition to a corporate project management system and provide the necessary tools to monitor the success of innovations in the implementation of military, double and civilian purpose [21].

At the level of project managers and project teams, it will become possible to include current and future work on projects in a unified corporate project management system, to transit to the efficient implementation of tasks set by management in a single conceptual field, as well as to work out documents which are optimal in terms of content when preparing contracts and negotiations with investors.

At the level of non-project specialists, diligence in terms of timing, quality and optimal resource costs will increase due to clear coordination of work parameters with project managers at the planning and distribution stage of these works.

The DIC enterprises projects, the management of the implementation of which can be improved: $R \& D$, introduction of new technologies and production re-equipment, production diversification and entry into new markets, new products development, state defence order implementation.

\section{E. Suggestions for future research directions}

Future research should be focused on the development of a methodological apparatus for the project management implementation within the framework of state programs of the Russian Federation in the field of DIC development, including:

- creating guidelines for the project management implementation within the framework of the existing state programs of the Russian Federation in the field of DIC development, taking into account the state defence order tasks;

- development of proposals to adjust existing regulatory legal framework for the introduction of project management mechanisms into the program tools for the DIC development;

- development of proposals to form indicative series and methods for assessing the effectiveness of state programs in the DIC development, formed using project management mechanisms.

\section{CONCLUSION}

Using modern approach and project management tools allows you to save up to $20-30 \%$ of time and about $15-20 \%$ of funds spent on projects.

This makes it possible to assert that project management is an effective mechanism for managing the state programs formation and implementation in the field of DIC development.

Project management at the DIC enterprises will contribute to more efficient $\mathrm{R} \& \mathrm{D}$, the introduction of new technologies and production re-equipment, solving the problems of diversifying production and entering new markets, as well as the successful development of new products and the state defence order fulfillment.

Today using modern project approach and its tools allows to save up to $20-30 \%$ of time and about $15-20 \%$ of funds spent on projects [21]. This allows us to assert that project management within the framework of the state programs formation and implementation, as well as at the DIC enterprises which implement them, will contribute to more efficient R\&D, the introduction of new technologies and production re-equipment, solving the problems of diversifying production and entering new markets. as well as the successful development of new products and WMSE products.

\section{References}

[1] Order of the Ministry of Economic Development of Russian Federation of April 14, 2014 No 26R-AU "On Approval of Methodological Recommendations for the Implementation of Project Management in Executive Bodies" ["Ob utverzhdenii metodicheskikh rekomendatsiy po vnedreniyu proektnogo upravleniya $\mathrm{v}$ organakh ispolnitel'noy vlasti”], 2014. (In Russ.). Retrieved from https://rulaws.ru/acts/RasporyazhenieMinekonomrazvitiya-Rossii-ot-14.04.2014-N-26R-AU/

[2] Decree of the President of the Russian Federation of February 23, 2017 No 91 "Fundamentals of state policy in the development of the defence industrial complex of the Russian Federation for the period up to 2020 and beyond" ["Ob utverzhdenii Osnov gosudarstvennoy politiki v oblasti razvitiya oboronno-promyshlennogo kompleksa Rossiyskoy Federatsii na period do 2025 goda i dal'neyshyyu perspektivu'], 2017. (In Russ.). Retrieved

https://www.garant.ru/products/ipo/prime/doc/400070256/

[3] P. Baguley, Project Management, Hodder education, 2008, 210 p.

[4] Federal Law of June 28, 2014 No 172-FZ "On Strategic Planning in the Russian Federation" [“O strategicheskom planirovanii v Rossiyskoy Federatsii”], 2014. (In Russ.). Retrieved from http://www consultant.ru/document/cons_doc LAW_164841/

[5] Resolution of the Government of the Russian Federation of November 11, 2010 No 1950-r "On approval of the list of state programs of the Russian Federation" [Ob utverzhdenii perechnya gosudarstvennukh programm Rossiyskoy Federatsii”], 2010. (In Russ.). Retrieved from http://docs.cntd.ru/document/902246112

[6] Portal of State Programs of the Russian Federation, 2020. (In Russ.). Retrieved from https://programs.gov.ru/Portal/analytics/quarter_report to government

[7] Ministry of Industry and Trade Russia. List of State programs, 2020. (In Russ.). $\quad$ Retrieved from http://minpromtorg.gov.ru/activities/state_programs/list/

[8] Information on the Results of the State Programs of the Russian Federation Examination, Bulletin of the Accounts Chamber of the Russian Federation, 2014, vol. 6. (In Russ.). Retrieved from https://ach.gov.ru/statements/

[9] Consolidated annual report on the progress of implementation and assessment of the effectiveness of state programs of the Russian Federation at the end of 2018 [Svodnyy godovoy doklad o khode realizatsii i otsenke effektivnosti gosudarstvennykh programm Rossiyskoy Federatsii po itogam 2018 goda], 2019. (In Russ.). Retrieved from

http://static.government.ru/media/files/O0oYQjWjuayDNFikaqyHUMq H8G4KD4pR.pdf

[10] G.A. Kompaneiceva, "Project approach: the concept, principles, factors of efficiency, Scientific and methodological electronic journal "Concept", 2016, vol. 17, pp. 363-368. (In Russ.). Retrieved from https://e-koncept.ru/en/2016/46249.htm

[11] I.V. Moiseev. "Issues of Using Project Management in Government Bodies", Economy, 2017, vol. 3, pp. 1-6. (In Russ.). URL: http://bujet.ru/article/318470.php?print=Y/

[12] N.V. Kandybko, "Project methods in management of defense-industrial complex innovation and investment activity", Moscow Witte University Bulletin. Series 1: Economics and Management, 2013, vol. 2(4), pp. $52-$ 58. (In Russ.)

[13] A Guide to the Project Management Body of Knowledge (PMBoK), Project Management Institute, USA, 1996, 2014, 2014, 2015.

[14] D. Cleland, and R. Gareis, Global project management handbook McGraw-Hill Professional, 2015.

[15] SMART is a technology for setting goals for their successful achievement [SMART - tekhnologiya postanovki tseley dlya ikh uspeshnogo dostizheniya], Motivation for life, 2020. (In Russ.). 
Retrieved from https://lifemotivation.ru/lichnostnyj-rost/smarttehnologiya-postanovki-tselej

[16] P.S. Zvyagintsev, "State Programs of the Russian Federation and their economic efficiency", The Bulletin of the Institute of Economics of the Russian Academy of Sciences, 2016, vol. 6, pp. 171-183. (In Russ.).

[17] Decree of the Government of the Russian Federation of July 17, 2019 No 903 "On Approval of the Rules for the Formation of a Consolidated Annual Report on the Implementation and Assessment of the Sate Programs of the Russian Federation Effectiveness, Amendments to Some Acts of the Government of the Russian Federation and Recognition as Lost the Force of Certain Provisions of Certain Acts of the Government of the Russian Federation" ["Ob utverzhdenii Pravil formirovaniya svodnogo godovogo otcheta o realizatsii i otsenke effektivnosti gosudarstvennykh programm Rossiyskoy Federatsii, vnesenii izmeneniy $\mathrm{v}$ nekotoryye akty Pravitel'stva Rossiyskoy Federatsii i priznanii utrativshimi silu otdel'nykh polozheniy otdel'nykh Akty Pravitel'stva Rossiyskoy Federatsii"'], 2019. (In Russ.). Retrieved from https://base.garant.ru/72301742/

[18] E.I. Kornelik, "Russian market for ERP-systems", Integral, 2016. (In Russ.). Retrieved from http: //integral-russia.ru/2016/08/31/rossijskijrynok-erp-sistem/
[19] Resolution of the Government of the Russian Federation of October 12 2017 No 1242 "Rules for the Development, Implementation and Evaluation of the Effectiveness of Pilot Individual State Programs" ["O razrabotke, realizatsii i ob otsenke effektivnosti otdel'nykh gosudarstvennykh programm Rossiyskoy Federatsii”], 2017. (In Russ.). Retrieved from https://base.garant.ru/71792342/

[20] Resolution of the Government of the Russian Federation of October 31, 2018 No 1288 "On the Organization of Project Activities in the Government of the Russian Federation" ["Ob organizatsii proyektnoy deyatel'nosti v Pravitel'stve Rossiyskoy Federatsii'], 2018. (In Russ.). Retrieved from https://base.garant.ru/71792342/

[21] A. Isekeshev: the use of modern project management methodology allows you to save $15-20 \%$ of funds spent on project implementation [A. Isekeshev: ispol'zovaniye sovremennoy metodologii proyektnogo upravleniya pozvolyayet sekonomit' $15-20 \%$ sredstv, ukhodyashchikh na realizatsiyu proektov], KazInform, 2010. (In Russ.). Retrieved from https://www.inform.kz/ru/ispol-zovanie-sovremennoy-metodologiiproektnogo-upravleniya-pozvolyaet-sekonomit-15-20-sredstvuhodyaschih-na-realizaciyu-proektov-a-isekeshev_a2330229 